\title{
Uniform buttons within the context of the collection of the Waldes Museum of Buttons and Fasteners*
}

\author{
Kateřina Hrušková
}

\author{
Mgr. et Mgr. Kateřina Hrušková \\ University of Hradec Králové \\ Philosophical Faculty, Institute of History \\ Rokitanského 62 \\ 50003 Hradec Králové 3 \\ Czech Republic \\ e-mail: hruskka2@uhk.cz, katerina.hruskova@msb-jablonec.cz \\ ORCID: https://orcid.org/0000-0001-6440-095X
}

Muzeológia a kultúrne dedičstvo, 2020, 8:4:5-21
DOI: $10.46284 / \mathrm{mkd}$.2020.8.4.1

Uniform buttons within the context of the collection of the Waldes Museum of Buttons

The study deals with uniform buttons in the collection of the Waldes Museum of Buttons and Fasteners in Prague-Vršovice, which was founded at the initiative of Prague industrialist and philanthropist Jindřich Waldes. Over the course of the museum's existence, from 1916 to 1945, the collection came to include more than 350 uniform buttons. This study tries to capture the significance of the collection at the Waldes Museum, both as exhibits in themselves, and as study material connected with the museum's publication work or the building of a specialised archive and library on the other. It also presents selected exhibits from the collection in question, together with other associated objects and specialised materials. The study draws on expert consideration of the preserved collection, original publications and materials from the Waldes Museum Archive ${ }^{1}$ and specialised literature.

Keywords: Button, uniform, collecting, Waldes Museum Collection, Jindřich Waldes

\section{Introduction}

Uniform buttons - that is, buttons made for a specific uniform - were, and still are, popular and highly-specific collectors' items that have been included to a greater or lesser extent in many a private and public collection. High-quality production, an attractive appearance and the added symbolic value of the button all helped to ensure that uniform buttons were gathered in specialised collections ${ }^{2}$ and in collections of a more general character. One such collection, created by the well-known factory-owner, collector and philanthropist Jindrich Waldes, later became the foundation of the collection held by the Waldes Museum of Buttons and Fasteners in Prague-Vršovice, which was active from 1916 to 1945. This study deals with the topic of uniform buttons within the context of that collection and institution, and thus the activities initiated by Jindrich Waldes - the creation of the collection, the initiative to create a collection of works on the button and the activities of the museum. Based on what we knew until recently,

\footnotetext{
* The study was compiled as the outcome of the Specific Research 2019 project, Výroba knoflíků v Anglii v letech 1750-1920 / The production of buttons in England 1750-1920, which was financed, under number 2116, by resources from a Student Grant Competition at the Philosophical Faculty of the University of Hradec Králové.

${ }^{1}$ Kept at the Museum of Glass and Jewellery in Jablonec nad Nisou. Contains 106 boxes of documentary materials and 6 boxes of printing blocks.

2 One example of such a collection is "The Pitt Collection", gathered by Ronald Pitt, which contains livery buttons predominantly for the service staff of British, Irish and other European aristocracy.
} 
it was assumed that uniform buttons were included within the collection merely to present the associated technology, which matches the profile of the part of the collection that focuses on the development of the button. However, it was shown during work with the assemblage that uniform buttons were gathered as a comprehensively processed collection of buttons in exactly the same way as other types. ${ }^{3}$ Preparatory work for the study included expert processing of the assemblage in question, which concentrated on identifying individual preserved objects in a comparison with other sets and specialised literature. Specific items from the uniform button collection will be presented as part of the study.

\section{Uniform buttons}

A button is a type of fastener. To quote an encyclopaedia which was popular in the days of the Waldes Museum, Masarykiv slovnik naucny, it is a "type of clothing clasp. It is made of metal, glass, porcelain, wood, coconut shell, vegetable ivory ..., bone, horn, antler, mother-ofpearl, hard rubber, galalith, celluloid. Buttons have either an eyelet or 2-4 holes in order that they may be stitched to clothing." ${ }^{4}$ Uniform buttons are solely intended for uniforms, defined in the same source as "a suit of the same cut and made of special material, prescribed at various corporations, for servants (livery), and in particular in the military. Its purpose is to distinguish them from civilians, and from enemies." 5 The definition in Ottiv slovnik (Otto's encyclopaedia) primarily mentions official military livery uniforms. The uniform, however, can also be work attire for the employees of transport companies, banks and factories (especially for publicfacing employees such as porters, drivers, tellers). It is typical of all uniform buttons that they are made based on a specific licence and a specific order.

Buttons complement specific haberdashery accessories, badges and clasps or patches. The Waldes Museum Collection includes several smaller assemblages that combine buttons and badges from the Czechoslovak army between the World Wars and the American army at the time of WWI.

A uniform button is an aesthetic and a symbolic object in one. It is a functional, visible and integral part of the uniform. The style or the creative execution matters little: it is a specific chain of symbols and everything else is merely insignificant decoration. This is one of the reasons why there are few artistic elements depicted on these buttons. The depiction of family coats-ofarms, city crests or military symbols is an exact reconstruction of the template. Stylisation only occurs in complex crests as a result of miniaturisation. The visual attractiveness is secondary. If, however, this is the reason for a button's inclusion in a collection, it is essentially suppressing the primary meaning of the object. As stated above, uniform buttons were frequently deemed to be examples of the high-quality processing of metals, irrespective of the symbolism. Deciphering them requires the ability to read the symbols and know their meaning. The uniform button is an object of identification. It tells us the identity of the employer of the person who wears it on his/her uniform. In other words, it represents the person or entity that the person in question serves. As for military or civil service uniforms, buttons can signify membership of a division and ranking. Uniform buttons can also represent far more complex phenomena. Military buttons might reflect the complexity of the structure of the army, something that can

\footnotetext{
${ }^{3}$ For example, a collection of buttons with components of Wedgewood, fabric buttons or buttons with miniatures.

4 Entry KNOFLÍK. Masarykìv slovnik naučný: lidová encyklopedie všeobecných védomostí. Díl III., H-Kn. Praha: Československý kompas, 1927, p. 1038.

5 Entry STEJNOKROJ. Masarykìv slovnik naučný: lidová encyklopedie všeobecných védomostí. Díl VI., R-S. Praha: Československý kompas, 1932, p. 956.
} 
easily be presented on as common and primitive an object as a button. Based on the button, the organizational classification of the soldier could be determined, often down to the level of battalion.

Most uniform buttons are made from metal by hammering - the more common method - or by casting. A high-quality tool or mould is required in both cases, with a quality engraver and model-maker at the beginning of the process and quality processing at the end. One of the characteristics of uniform buttons is their high quality. Diminished legibility and plasticity of the relief are the result of wear or exposure to unsuitable conditions. ${ }^{6}$ As far as metals are concerned, the standard is for buttons to take on the appearance of silver and gold, whether through use of base metals and their alloys or by plating with precious metals. Other materials, such as fabric or thread (crocheted or knitted), can also be used for uniform buttons. This is typical of livery, when the button puts the finishing touches on the overall appearance of the specific traditional attire. We can observe this type of livery button at the Imperial Court in Vienna. ${ }^{7}$ Less common materials include pressed horn, used for the military buttons of the Royal Ghurkha Rifles regiment ${ }^{8}$ that serves in the British Army.

Let us not forget, however, that the button is a functional object too - a fastener - that in some cases was initially used as decoration, such as buttons for epaulettes and collars. In terms of how the button is attached to the fabric, an eyelet is undoubtedly typical of uniform buttons. Buttons with holes are practically non-existent. This, too, ranks them as more luxurious products. ${ }^{9}$

As was the case with other types of product, uniform buttons have undergone specific technological developments. Between 1790 and 1800, they were typically constructed using the principle of a wooden core coated in metal. They were stitched on to the fabric through the threaded reverse side of the button or through an eyelet made of catgut, as was typical of the buttons worn by the French army. Whereas fashion production struggled with the decline of craft processing and creative form in the second half of the nineteenth century, the production of uniform buttons was creatively based on the classic forms prescribed by laws or traditions. The buttons were also made of quality materials since it was expected they would be used for a long time.

This naturally offers up a comparison of uniform buttons and standard buttons produced for civilian fashion. One difference is the geographical demarcation of their use. We can say about fashion buttons that a particular design is popular in a certain area - Paris, Italy or across Europe - or that the customers who buy them are drawn from the middle classes of a certain region or from a rural area, etc. In general, we can say that fashion buttons are worn wherever they can be sold. Any trader can essentially order a particular design from a manufacturer and sell it anywhere. One end result is that it is entirely up to the customer how to use the button. In comparison, uniform buttons are ordered by a specific customer and have a specific field of usage. They are worn where specific uniforms are worn and must be stitched on in the prescribed way. It must also be noted, of course, that uniform buttons might be used more

\footnotetext{
${ }^{6}$ This most concerns items found in the ground.

${ }^{7}$ More in: SEIPEL, Wilfried, WIECZOREK, Alfried (eds). Des Kaisers teure Kleider: Festroben und Ornate, Hofuniformen und Livreen vom frühen 18. Jahrhundert bis ins Zeitalter von Fran₹ Joseph I. und Elisabeth. Wien: Kunsthistorisches Museum, 2000.

${ }^{8}$ The Gurkhas are soldiers from Nepal that serve in various foreign armies, including the British army.

${ }^{9}$ Buttons with holes were long considered to be inferior and were mainly used for inside fastening or bed clothing. Fashion buttons with holes did not appear regularly until the end of the nineteenth century.
} 
than once, recycled on folk attire, for example, or used as a souvenir or amulet. This, however, is contrary to the original intended use. Men from the Mapuche tribe, ${ }^{10}$ for example, wear belts decorated with buttons from French military uniforms ${ }^{11}$ as a symbol of higher social standing.

In contrast to fashion buttons, the appearance of uniform buttons is consistent. Visual transformation comes with systemic or organisational change; a new ruler in a monarchy, the death of a leading member of the line in the case of livery buttons, or a change of "visual style" for enterprises or public administrations. Such transformations are associated with a change in social conditions. One example is found with changes in the Austrian Monarchy in 1804 and 1867 which required the replacement of uniform buttons in their entirety. As with fashion buttons, uniform buttons are manufactured in batches, with the total number depending on the number of people that will wear those uniforms. If we stick with the above example, it can be noted that before the First World War, some 415,000 men ${ }^{12}$ were part of the Imperial and Royal Military in Austro-Hungary, so winning such a contract would have been very profitable for a button-maker.

Neither should it be forgotten that uniform buttons frequently became the inspiration for purely fashionable goods. The mass production of buttons made of pressed metals began in the 1870s. The second half of the nineteenth century is generally described as the era in which artistic craft waned. Gottfried Semper remarked on this in his work Wissenschaft, Industrie und Kunst (Science, Industry and Art). This was caused by succumbing to short-lived trends in fashion, the need to keep the price down and the short lifetime of the product accepted as a result. Manufacturers and merchants were looking for new designs wherever they could, and so began using uniform buttons as templates. Perhaps the most widespread was the use of an anchor and rope, a motif that appears on buttons to this day. Fictitious heraldic motifs are also common. It is important, in order to provide a full picture, to emphasise once again the aspect of quality and the lifetime associated with this shift in production. Fashion buttons are typically made of far cheaper materials that are susceptible to degredation. Ješek Hoffman remarks on this era with the words, "Alas, this stage of development is the fall of artistic industry. It is then in particular that the era of stamped metal begins, manufactured in great quantities and without any feeling". ${ }^{13}$ He goes on to describe the present as a "confused, unrefined" time "suffering from a lack of tradition".

Uniform buttons are, on the one hand, demanding from the perspective of the collector and the collection curator, since they require knowledge of heraldry, state symbolism and the symbolism of other institutions, companies or societies, as well as the ability to correctly recognise individual details in the miniaturised depiction of the relevant symbol. On the other hand, given the correct identification, the button can precisely communicate its function, motif, era and area of creation, and in many cases the manufacturer too. This is often impossible for fashion buttons, at least without further contextual information. Uniform buttons can be used to create different series which are conditional on membership of an army, family, region, profession, manufacturer and the like, making them even more attractive.

\footnotetext{
${ }^{10}$ The Mapuche are given the post-Columbian name of the Araucanian in Leopoldina Auzingerová's text.

${ }^{11}$ AUZINGEROVÁ, Leopoldina. Berlínskými musey. Studie věnovaná knoflíku. In: Zprávy musea knoflikẻ Jindrich Waldes Praha-Vršovice (Zprávy Waldesova musea knofíkủ), vol. 1, no. 1, 1916, p. 3.

12 JUNG, Peter. Rakousko-uherská armáda za prvni svétové války. Brno: Computer Press, 2001, p. 4.

${ }^{13}$ HOFMAN, Ješek. Prùvodce sbirkami Waldesova muzea v Praz̧e-Vršovicích. Praha: Politika, 1916, p. 16.
} 


\section{The Jindrrich Waldes Collection, the Waldes Museum}

Jindřich Waldes (1876-1941) was a well-known factory-owner, collector and philanthropist, the co-owner of a successful company of global renown, Waldes \& Co., based in PragueVršovice, with branches in Europe and the USA. The profits earned from his business not only enabled him to become an industrialist, but to devote his attention to collecting, mainly in the sphere of art. ${ }^{14} \mathrm{He}$ was entirely fascinated by buttons. This is plainly confirmed by his fundamental stance, that "the button, or indeed the way clothing is fastened, is a gauge of national culture in the true sense of the word and sometimes the way in which the culture of a nation is expressed". ${ }^{15}$ His tendencies were almost evolutionist when it came to folk buttons and fasteners. He associated the button with other fasteners very closely, wanting to present the whole within the context of clothing in general for individual regions and for individual ethnic groups. However, he was also interested in the chronological development of buttons and fasteners in relation to technology and materials, fashion, art and culture in general. Waldes viewed the button entirely positively, as a singular representative of the level of technology, craft and creativity achieved by the group in question. We might say that he viewed this human culture, documented through the button, as the "successful culture" of which Zdeněk Kratochvíl spoke in his work "Konflikt intepretacî", in which he says: "A successful culture is built on its technological and organisational ability, if possible harmonised with the emotional needs of individuals and their social bonds" ${ }^{16}$

Waldes began studying buttons at the end of the nineteenth century, at that time as an amateur. It was also then that he most likely started his collection. He was able to expand on that collection during numerous journeys abroad, around Europe and to the USA. He devoted his time to the button from various angles for many years. ${ }^{17}$ He built contacts with experts, specialised institutions and magazines and endeavoured to lay the foundations of the "science of the button", although he never harboured ambitions of becoming a scientist himself. Instead he tried to bring in other experts for this. His first significant initiative, apart from building the collection, was to commission a far-reaching book about the button from Eduard Maria Schranka, ${ }^{18}$ a Viennese writer whom he called his friend. The book was handed over at the end of 1915, but did not meet Waldes' expectations of a collective, all-encompassing monograph. After consulting other experts, he diplomatically said that the work required expanding. Schranka, we can assume from this, did not prove to be the right author. The book was never published, but one copy of the manuscript is stored in the Waldes Museum Archive. In this manuscript, one chapter in this unique work looks at the uniform button. The work

\footnotetext{
${ }^{14}$ Waldes' collecting activities are considered in the following publication: Patrik Šimon. Jindrüch Waldes: Sběratel umèní. Praha: Eminent, 2001. His life story and business activities are also c in detail in studies by Martin Sovák and Eva Králová, which were published in the anthology HRUŠKOVÁ, Kateřina et al. Sborník semináre k 100. výroči otevrèni Waldesova muzea. Jablonec nad Nisou: Museum of Glass and Jewellery in Jablonec nad Nisou, Praha: Kotěrovo centrum architektury, o. p. s, 2018.

${ }^{15}$ WALDES, Jindřich. Moje museum. In: Zprávy musea knoflikư Jindrich Waldes Praha-Vršovice (Zprávy Waldesova musea knofikii), vol. 1, 1916, is. 1, p. 1.

${ }^{16}$ KRATOCHVÍL, Zdeněk. Konflikt interpretací? In: Lenka OVČÁČKOVÁ a kol., O piovodu kultury - biologické, antropologické a bistorické koncepce kulturní evoluce, Praha: Academia, 2017, p. 14.

${ }^{17}$ In his declaration on the foundation of the museum in the very first issue of the museum magazine Zpráy musea knofiki, he states: "I have been interested in the button for several decades now". Given his birth date, we can assume that his interest therefore began at the end of the nineteenth century.

${ }^{18}$ Eduard Maria Schranka, b. 21 September 1850, Planá, d. 10 August 1916, Vienna. For more information, see https://www.geschichtewiki.wien.gv.at/Eduard_Maria_Schranka.
} 
remains available in the Waldes Museum Archive, and is described in more detail below.

Waldes was also responsible for opening a museum, which eventually took on his own name - the Waldes Museum: Collections of Clothing Fasteners. The museum began life in 1916. ${ }^{19}$ From the very outset it had the ambition of becoming a full scientific institution, where collection-building and exhibition work would be only two of many activities. Waldes endeavoured to make his museum an institute in the same vein as the Museum of Decorative Arts in Prague or the Kunsthistorische Museum in Vienna. However, the museum only took this direction until 1919, when its first director and main scientific officer, Jan Ješek Hofman, departed. After his departure, the museum concentrated only on exhibition and awarenessraising work. The collection was subsequently expanded only slightly beyond the scope of the museum's first four years. ${ }^{20}$ While Waldes concentrated on the button from the very beginning, museum director Ješek Hofman was interested in the phenomenon of fasteners as a whole. Both, however, drew on the assumption that clothing is a basic human need, that the fastener had become an integral aspect of this, and that it had developed progressively as far as basic form and creative and artistic processing were concerned. Hofman was very active in building contacts with various museums and institutions all over the world. He even tried to build contacts with the Metropolitan Museum in New York, at least in exchanging publication activity. He worked intensively on the expert processing of collections and on building expositions and had a healthy critical approach. The museum stagnated as a result of his departure, as well as Waldes' own revised view of the museum. The museum eventually closed in 1945. After travelling to and fro, a significant part of its collection became part of the collection fund at the Museum of Glass and Jewellery in Jablonec nad Nisou (MSB collection), temporarily at first (in 1973) and then on a permanent basis (on 1 January 1978). ${ }^{21}$ Buttons and fasteners were sorted there under two separate sub-collections, ${ }^{22}$ which jointly make up the "Waldes Museum Collection". This was declared an item of cultural heritage in 1999.

\section{Dr Eduard Maria Schranka: Der Knopf}

As Waldes wrote in 2016, "It seemed rather disagreeable to me that there is no extensive work, no encyclopaedia of the button as it were, in any world literature". ${ }^{23}$ This explains his plan to bring out a specialised publication, the writing of which he entrusted to Eduard Maria Schranka. Unfortunately, we do not know when Schranka began working on the book. All we do know is that he presented Waldes with a typescript of a manuscript in 1915. It was written in German, was 120 pages in length and remains in the Waldes Museum Archive to this day. There are language corrections and a number of remarks, written in a minimum of two hands. We cannot say with certainty whether this was the only copy. The monography was entitled

\footnotetext{
19 "Button" appeared in the name until 1918, when the museum was called Waldesovo museum knoflíků a šatních spínadel (Waldes Museum of Buttons and Clothing Fasteners).

${ }^{20}$ The activities of the museum are considered in more detail in HRUŠKOVÁ, Kateřina. Sbirka Waldes. Jablonec nad Nisou: Museum of Glass and Jewellery in Jablonec nad Nisou, 2014, and in the paper HRUŠKOVÁ Kateřina, Waldesovo muzeum knoflík a spínadel v letech 1916-1945. In: Sborník seminárée k 100. výroči otevreni Waldesova muz̨ea. Jablonec nad Nisou: Museum of Glass and Jewellery in Jablonec nad Nisou, Praha: Kotěrovo centrum architektury, o. p. s, 2018, p. 30-33.

${ }^{21}$ Number in Centrální evidence sbírek (Central Record of Collections) administered by the Ministry of Culture of the Czech Republic: MSB/002-05-14/255002

22 The current sub-collections take the following names: Sbírka Waldes - spínadla a oděvní doplňky (Waldes Collection - Fasteners and Clothing Accessories) and Sbírka Waldes - knoflíky (Waldes Collection - Buttons).

${ }^{23}$ WALDES, Jindřich. Moje museum..., p. 2.
} 
Der Knopf. ${ }^{24}$ Waldes, however, was not satisfied with the book. The question is, of course, what his reason for deciding not to publish actually was. He wrote the following about the publication in his text "Moje museum" (My museum): "The material gathered so far has been provided with thorough and objective criticism and the proposals and stimuli that reached me on this occasion led me to the decision not to publish this monography in the format originally intended". ${ }^{25}$ As his reasons, Waldes cited the aim to deal with the subject-matter for regions that had not until then been researched on account of the ongoing wartime conflict, and a desire to expand the publication as a whole with the contribution of other experts. My own view is that one of the problems was that Schranka considered the button too generally. Waldes saw the button as a fastener, an important object on clothing, an object that put the finishing touches to clothing and shaped it. Schranka took a broader view, considering, for example, other dimensions such as semantics, traditions, legends and the button in song or riddles. The text reads more like excerpts or notes from various types of source and literature. Waldes was most interested in the button as a fastener from the very outset. He was primarily concerned with what Schranka termed the "dress button", to which he devoted only one of many subchapters. On the other hand, it is clear that Schranka carried out a considerable amount of research. Moreover, he defines the science of the button, which he termed "Butonik", in the first chapter. His intention, however, never took hold.

Dr Schranka succumbed to serious illness in August 1916. There is nothing to suggest that anyone else took up the reins of his task. This uncompleted "project" shows how considerable Waldes' efforts were at that time to devote intense attention to the button. It must also be noted that Waldes evidently valued the work which Schranka had produced.

The work has a strong pro-German slant. It only deals with German-speaking countries and the northern Czech borderland. We can only speculate as to whether this was a result of the wartime period, with limited opportunities to travel, or Schranka's linguistic limitations. His literary background research is mostly based on German publications, with only two English publications. From a modern-day perspective, though, this bibliographical background research is the most valuable part of the work. It contains a number of titles that are very hard to find these days. One article is particularly worthy of note as far as uniform buttons are concerned. It was written by Baron Rudolf Potier $^{26}$ in $1876,{ }^{27}$ is entitled Kurzwarenindustrie (Knöpf) und Heerwaren, and looks at the issue of Viennese button production for the army. It points to the significant role of army contracts in the development of this industry, claiming that "[s]oldiers were the apostles of the button industry in Austria". ${ }^{28}$ Potier also mentions period collections of uniform buttons ${ }^{29}$ and he does not ignore an exhibition of buttons for hunting uniforms and livery that was held in the French pavilion at the World Fair in Vienna in 1873.

It must also be noted, however, that I came across a whole range of errors and inconsistencies

\footnotetext{
${ }^{24}$ Museum of Glass and Jewellery in Jablonec nad Nisou, Waldesova Museum Archive (hereinafter MSB WM Archive), box M61.

${ }^{25}$ WALDES, Jindřich. Moje museum..., p. 2.

${ }^{26}$ Full name: Rudolf Franz Josef Baron Potier des Echelles (1836-1912).

${ }^{27}$ The article was published as part of a series in the periodical Wochenschrift des Niederösterreichischen Gewerbe-Vereines: Fachblatt für Gewerbe, Industrie und Handel, vol. 37, p. 452-453, accessed 6 December 2019, https://books.google.cz/ books?id=35thXdADGpMC\&pg=PA452\&hl=cs\&source=gbs_toc_r\&cad=4\#v=onepage\&q\&f=false

${ }^{28}$ SCHRANKA, Eduard Maria (1915), Der Knopf: Ein Stückechen Kulturgeschichte, Praha, 1915, typescript of a manuscript supplemented with corrections, rewritten at the Waldes \& Co. plant, Prague - Vršovice, MSB WM Archive, box 64, p. 23.

${ }^{29}$ SCHRANKA, Der Knopf..., p. 9.
} 
when working with Schranka's text and checking the information given. The use of the text therefore demands a highly critical approach.

How, then, does Schranka work with the uniform button? In the section devoted to history, he unfortunately only considers buttons for military uniforms. He deals with the use of buttons in the Austrian army, when between 1700 and 1867 - that is, until the first major overhaul of uniforms - two types of button were used: gold-plated for superior ranks and silver for subordinate ranks. He also mentions buttons as military insignia which in certain cultures had uses other than on clothing alone, such as in the decoration of a weapon. As examples, he presents the "fokoš", a hussar's axe, and decorations on the club-shaped staffs of the Xhosa people. The general shortcomings of Schranka's work - brevity, jumping from topic to topic are clearly manifested in the passages about military buttons.

Schranka categorises buttons in the chapter entitled "Die Nomenklatur der Knöpfe". ${ }^{30}$ At the beginning of the chapter, he sorts buttons by material, use, shape, wearer, name, location of production and method of attachment. In the list which follows, which contains 484 entries, he combines all categories together in alphabetical order. We can find uniform buttons, for example, in the entry "Armee Knöpfe" (army buttons), under which there are only two categories. The first includes buttons with two eagles - meaning the buttons on uniforms of civilian imperial and royal employees or in the army. The second group includes buttons showing the initials F.J.I., which is a specific type of military uniform button on the hat, referring to Franz Joseph I. Another type of button mentioned is the "Artilerieknöpfe" (artillery button), the description and development of which he devotes considerable attention to, and which is found again under "Militërknöpfe" (military buttons). "Beamtenknöpfe" (official buttons); "Bedientenknöpfe" (service buttons), including livery buttons and buttons for footmen; and "Berufsknöpfe" (buttons associated with an occupation), which he sorts according to the type of attire, are also included in this group. "Militärknöpfe" is the most wide-ranging entry in the whole list and contains buttons sorted according to the ranks in the Austro-Hungarian army. The list also includes the shorter entry of "Soldatenknöpfe" (soldiers' buttons), which makes reference to the entry mentioned immediately above. Livery buttons are found under the entry "Wappenknöpfe" (buttons with emblems).

Schranka's work could have been a good springboard for a genuinely all-encompassing publication, probably an encyclopaedia. It should be noted, however, that the book which Waldes originally intended was never published.

\section{The uniform button in the Waldes Museum Collection}

Unfortunately, we cannot say how many uniform buttons there were in the collection donated to the museum by Jindřich Waldes. The collection expanded considerably after the museum began its activities, between 1916 and 1920. Although the museum gradually began focusing on fasteners in general, buttons retained a dominant position as far as numbers and expert attention were concerned. Wherever the production material and technology or the theme were the same for both groups, mainly in the case of ethnographic assemblages, buttons and other fasteners were put on display and published together.

The museum presented itself outwardly mainly through its ethnographic collection, archaeological finds and valuable, crafted, artistic collections of English and French origin from the eighteenth and nineteenth centuries. Profession buttons, buckles and badges were

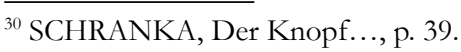


never included in these promoted groups, in spite of the fact that there are significantly more of them in comparison with the collections mentioned above. The original reference numbers are found on many buttons to this day. These numbers indicate that they became part of the collection during the first major wave of acquisition after 1916 and were part of at least the first, and in some cases even the second, version of the exhibition.

The collection contains a fine range of uniform buttons - buttons made for state administration, meaning military and civilian uniforms, including regional or municipal government. There are also buttons for private subjects, in particular livery buttons from the world of the aristocracy. These are joined by buttons used on the uniforms worn by employees of transport companies, banks or trading and manufacturing companies. For the sake of completeness, it is only right to also mention club uniforms. ${ }^{31}$

Uniform buttons were included in the collection as one of many examples of the form which buttons can take. This achieved the aim of the museum to present fasteners in all their forms.

At the same time, uniform buttons are a good example of how comprehensive the collection and the work of the museum and its staff and associates was in relation to individual topics. The museum programme aimed to enable researchers to study all possible materials, among which three-dimensional objects were merely one category. Actual collection pieces were accompanied by specialised literature, archival background research and a variety of images photographs and negatives, reproductions and graphic art. Studies, essays and short stories on individual topics were published in the special periodical Zprávy Waldesova muzea (Waldes Museum News).

Even though, according to the circumstantial evidence we have, uniform buttons represented about $6.5 \%$ of the collection, making it a relatively sizeable assemblage in comparison with other collections, these buttons were never given as much attention in the exhibition and in the presentation and promotion of the museum as other assemblages. It is clear from all the preserved materials connected to the activities of the museum, however, that uniform buttons were seen and treated as a specialised subject-matter at the museum.

The assemblage was generally conceived as a collection of fasteners, within which the collection of uniform fasteners was predominantly made up of buttons, followed by clasps and buckles. The collection was supplemented by around three dozen military badges. The three-dimensional collection at the museum contained more than 15,000 pieces on record. The original reference numbers preserved on collection items testify to the initial size of the collection, as do printed materials, in particular a guidebook to the exhibition from $1918,{ }^{32}$ period photographs and lists of additions published in certain editions of Zprávy Waldesova musea. The original documentation, taken from 1916 onwards, mainly for items intended for the exhibition, unfortunately no longer remains.

Acquisitions for the collection were made through donations and systematic purchasing, primarily at auctions in Vienna, Berlin, Leipzig, Munich and, of course, Prague. Purchases were handled by associates of the museum and by its director, Ješek Hofman. Jindřich Waldes and his wife Hedvika were also involved in acquisitions, bringing home pieces for the collection from their frequent trips abroad. Given that most purchases were made abroad, the number of acquisitions was also influenced by customs burdens. This was partly compensated by the

${ }^{31}$ HUGHES, Elizabeth, LESTER, Marion. The Big Books of Buttons. Augusta, Maine: New Leaf Publishers, 1993 , p. 773.

${ }^{32}$ HOFMAN, Ješek. Prưvodce sbirkami..., 1919. 
fact that purchases in Germany were officially made through the Dresden branch of Waldes \& Co. Keeping track of additions to the collection is, unfortunately, hampered by the fact that no records remain for the collection and no additions book or reference cards have been found, even though various materials that we still have tell us that proper records were made. ${ }^{33}$ The timeline of acquisitions can be partially reconstructed from the accounting documents we have and from information about new acquisitions in Zprávy Waldesova musea. Here we can see that uniform buttons were mainly obtained as gifts, with a few exceptions. Most of the uniform assemblage was included in the collection at the first stage in the life of the museum, from 1916 to 1919, while there was greater acquisition activity in $1934,{ }^{34}$ when Czechoslovak military badge collectors' cards became part of the collection.

Let us now concentrate on some of the acquisitions published. The first issue of the second volume mentions a single purchase of uniform buttons: "an assemblage of opulent livery and costume buttons". 35 "Two impressions of livery buttons" 36 were received as a gift in the second half of 1918, sent to the museum by the Duke Schwarzenberg Central Archive in Český Krumlov. Another "36 uniform buttons" ${ }^{37}$ were received from M. Göbel from Munich. F. A. Borovský, Director of the Museum of Decorative Arts, donated a "livery fastener" to the museum collections at around the same time. Scenographer Karel Štapfer then donated other "dress and livery buttons" to the museum. The fact that the description is only general, however, means that we have been unable to specifically identify the acquisition.

The resulting collection contained buttons made for customers from Europe, the Near East, North and South America and North Africa. They were made sometime between 1800 and 1930. The contemporary assemblage of all buttons concentrated in the Waldes - Buttons collection (sig. WK) numbers 5,724 pieces, of which uniform buttons account for 361 . The uniform collection contains buttons made for uniforms used by the organisational units of state administration, the army, public transport, and for non-governmental customers - the aristocracy, churches, banks, trading companies, private transport companies and factories. Here we should also mention a genuine rarity, the so-called "exposition buttons", which were created for the uniforms worn by staff at various trade fairs or exhibitions, often of continental or worldwide significance It is therefore an assemblage that presents the maximum possible range of the uniform button. On the other hand, it is clear that it was essentially created by chance and that the composition is imbalanced. The lion's share is taken by civilian buttons used by state administrations in Central Europe. The smallest group consists of buttons for private corporations.

\section{Military uniform buttons}

The buttons on military uniforms are "a typical symbol from the political, social, national, psychological and cultural perspective". ${ }^{38}$ They are frequently the only part of the uniform to

\footnotetext{
${ }^{33}$ A new inventory of pieces was carried out as of 1917. Pieces were also sorted in four separate reference groups: collections, duplicates, attire picture archive and library. There was, alongside this, a so-called scientific or research record, which ordered pieces chronologically and technologically. The scientific record was maintained in Czech and German. Zprávy Waldesova muzea, Sbirky, vol. 2, no. 1, Praha-Vršovice 1917, p. 25.

${ }^{34}$ According to the information on the reverse of the card.

${ }^{35}$ Sbírky. In: Zpráry Waldesova muzea knoflikui, vol. 2, 1917, no. 1, p. 24.

${ }^{36}$ Sbírky. In: Zpráyy Waldesova muzea knofliki, vol. 3, 1918, no. 3-4, p. 69.

${ }^{37}$ Sbírky. In: Zpráuy Waldesova..., p. 69.

${ }^{38}$ VOGELTANZ, Jan. Stejnokroje 1848-1849. České Budějovice: Karmášek, 2009, not paginated.
} 
endure as a reminder. They are an aspect of military symbolism and their use is governed by binding regulations. As identifiers of membership of an organisational unit of the army, they are just as important as the colour of the uniform, badges, symbols and markings.

These are generally buttons made under public contracts. Three-dimensional processing is typical. The use of an established heraldic motif is not a condition, in contrast to the uniforms worn by state administration. The symbols are commonly associated with the characteristics of weapons or the number of the division. The colour of the metal used differs for different ranks.

The oldest uniform buttons in the collection were pieces from the Roman Empire that were used on military attire. Unfortunately, these have not been preserved. Only Roman legionnaires' buttons remain in the collection to this day. The largest part of the assemblage consists of buttons from the time of WWI that became obsolete on account of the political and social changes about to occur. These buttons were mainly worn by the soldiers of Austro-Hungary, Prussia, the Ottoman Empire and Tsarist Russia. The only tableau of military buttons from the permanent exhibition to have been preserved is highly valuable in this regard.

There are also examples of buttons worn by British infantry after 1855 and two buttons from the US Army, General Service, used by all branches of the Service, except the Engineers. According to the black veneering, these date back to 1902-1918 (Figure 1).

A button worn in France by the Republican Guard from sometime around 1793 is also highly-prized.

The collection also contains buttons from the Czech lands. There are buttons used by the uniformed bodies of the Czechoslovak Republic between 1921 and 1930 and collector's cards with buttons and badges from after 1930. These cards are also one of the last documented and recorded acquisitions made for the museum collection, in 1934.
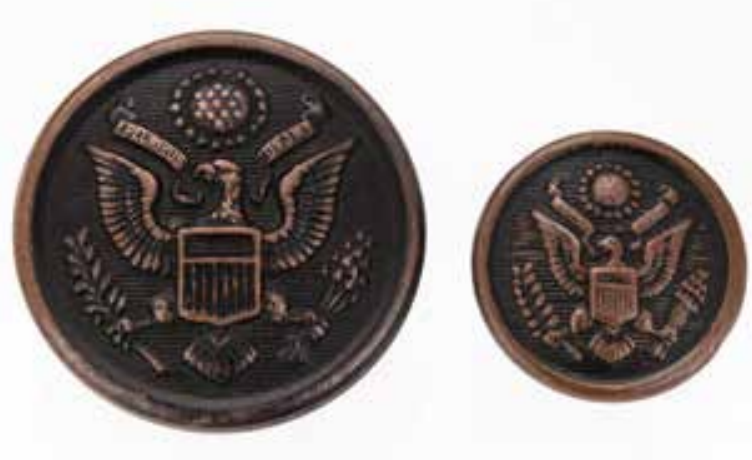

Figure 1: Uniform Buttons, The Great Seal of the United States, blackened bronze, Scovill MFG CO Waterbury (big) / BUTTON WORKS NY (small), USA, 1902-1918, Ø 15.5-23.0 mm, MSB collection, inv. no. WK1843
Buttons on the civilian uniforms of state administrations

The largest assemblage of uniform buttons as far as number is concerned is that of civilian uniforms for state administrations. Buttons from Austro-Hungary and the Germanic lands, in particular Bavaria, Württemberg and Saxony, prevail. These are found in the collection in several variations and duplicates. This is again caused by the change of symbolism in the interwar period. There are also buttons featuring the state emblem of the Kingdom of Prussia. Two interesting series of buttons also feature here. The first is a set of buttons for the state authorities of the Electorate of Hesse from the end of the nineteenth century (Figure 2). These consist of a coat of arms and an indication of the particular authority. The second series features quality brass buttons worn by the officials of Russian guberniya (governorates) from before WWI. 

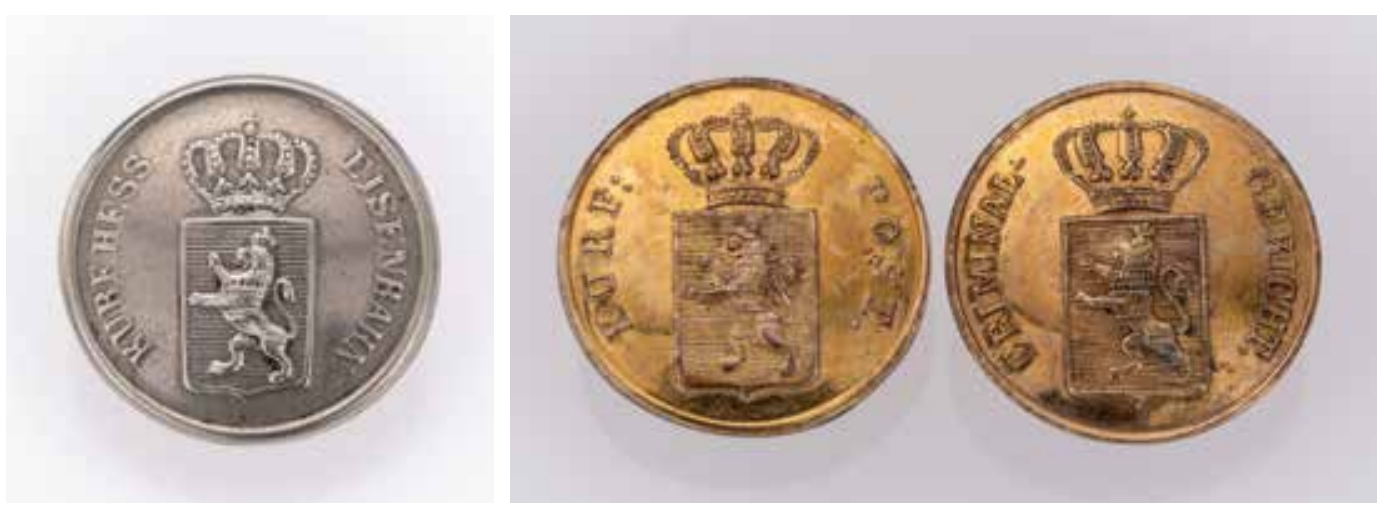

Figure 2 (a,b): Buttons, Electorate of Hesse Authorities: railway, post, criminal court, brass or tin alloy, I. Forstmann, Cassel, Electorate of Hesse, after 1843, Ø 21.7-23.7 mm, MSB collection, inv. no. WK1722, WK1724

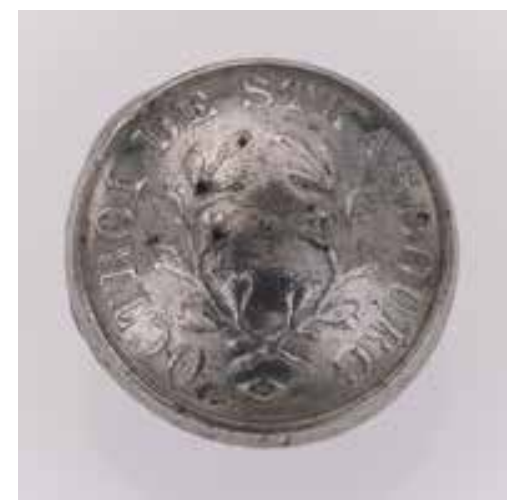

The buttons, which reflect a specific profession under the heading of state administration, were worn by people such as post office workers. One valuable example is a button from the uniform of a worker at the Strasbourg excise duty collection authority (Figure 3).

As far as buttons featuring a state emblem are concerned, we should certainly not forget the "informal" emblem of the French Republic, where the emblem is accompanied by Ordre national de la Légion d'honneur and a chain, dating back to the time after 1881, along with the motto "Liberté, Egalité, Fraternité". The emblem was used after 1902.

Figure 3: Button, Strasbourg Office for the collection of excise duty, tin alloy, France, until 1871, Ø $22.6 \mathrm{~mm}$, MSB collection, inv. no. WK1677

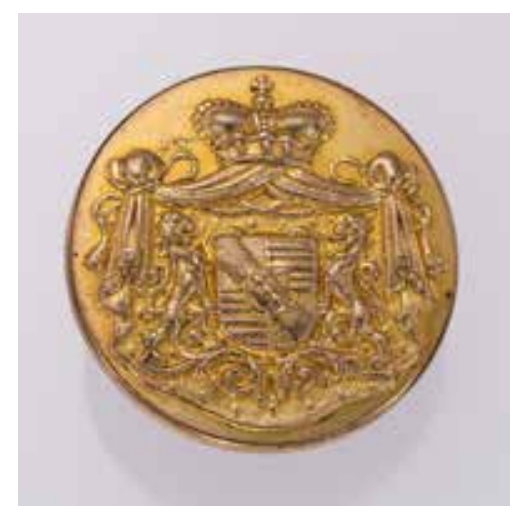

Figure 4: Livery button, made for House of Beaufort-Spontin, brass, Heinrich Jauner, K. K. Hofkeammergraveur, Wien, Austria, 1850-1900, Ø $28.3 \mathrm{~mm}$, MSB collection, inv. no. WK 3223
Buttons showing the state emblems of Bolivia and Chile are part of the same group, in both cases accompanied by a badge in the same style.

\section{Livery buttons}

There are many types of livery buttons. As is also the case in other collections, the most abundant are the livery buttons of the aristocracy. One example is a button bearing the coat of arms of the Beaufort-Spontin family (Figure 4). A variant of the coat of arms is used after 1813, when the family settled in the lands of the Austrian monarchy. The miniature of the coat of arms is not particularly discernible on account of the many figures.

Another interesting chapter is written by the buttons worn by the staff of church dignitaries. These invariably show the single, specific emblem of one person and the buttons can therefore be dated with accuracy. By way of example we present a button showing the crest of ThDr. Bedrrich Egon Fürstenberg, Cardinal and $6^{\text {th }}$ Archbishop of Olomouc from 1853 to 1892 (Figure 5). 


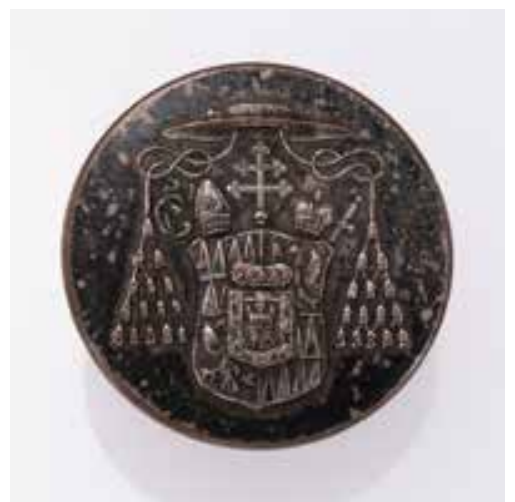

Figure 5: Livery button, made for House of ThDr. Bedrüch Egon Fürstenberg, silvered tin alloy, TW WIEN SUPERFEIN, Wien, Austria, after 1853, Ø $29 \mathrm{~mm}$, MSB collection, inv. no. WK1776

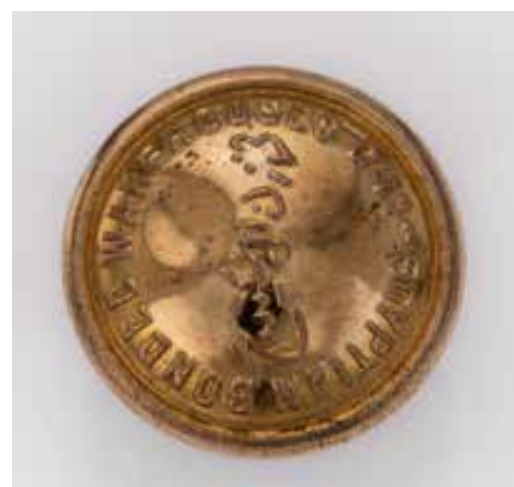

Figure 6: Button, made for Egyptian Bonded Warehouses G. L., brass, 1900, $\varnothing 22.5 \mathrm{~mm}$, MSB collection, inv. no. WK1792

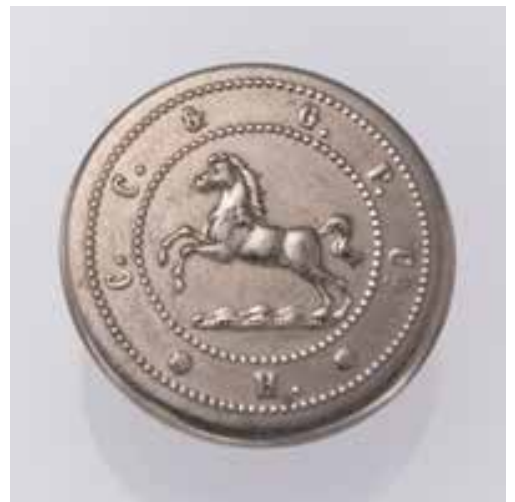

Figure 7: Button, made for tire company C.C. G.P. COH, zinc alloy, Germany, after 1895 , Ø $25.2 \mathrm{~mm}$, MSB collection, inv. no. WK1732

\section{Other uniform buttons}

As mentioned above, employees in other professions also wear uniforms. The collection contains buttons that were mostly worn by employees in the transport sector, which in our case means railways, trams and maritime navigation. The first of these is represented by a button featuring a stylised locomotive and the inscription BerlinAnhal.tische Eisenbahn, i.e. the Berlin-Anhalt Eastern Line, from sometime around 1860. Railways are also represented by an aesthetically attractive button collar badge from 1914, worn by the employees of the Austro-Hungarian railway. The dominant feature is the motif of a winged wheel, in the highly-purist stylisation that belongs to the pre-War period. The Americas are represented in this group by a button from the uniform worn by the Mississippi Delta Railroad in USA. The railway uses the emblem, in the form of a triangle, to this day.

Tram transport is represented by a button from the uniform worn by employees of the German city of Kassel (WK02037), accompanied by the city's crest. A company which was responsible for tram transport in what is now Turkey is represented by two buttons from the uniform worn by the Belgian banking institution Société Générale de Tramways, founded in 1874 by Banque de Bruxelles as a financial institution focussing exclusively on the development of tram transport abroad, in this case the Ottoman Empire. The inscription TRAMWAYS on the front is accompanied by the symbol of a half-moon and a five-pointed star. Shipping is represented by buttons from the uniforms worn at the Koninklijke Hollandsche Lloyd Company, a Dutch shipping company headquartered in Amsterdam. The company was founded in 1899.

Trade is represented by a button from the uniform worn by an employee who evidently worked at the Egyptian Bonded Warehouses G. L. (Figure 6). Bonded Warehouses were found in port cities and served as warehouses for goods before clearance through customs. Manufacturing, meanwhile, is represented by a button from the uniform worn by factory employees of a company from Hanover, Germany that made pneumatic tires for vehicles of all kinds, marked with the initials C.C. G.P. COH (denoting Continental-Caoutchouc und Gutta-Percha Compagnie). The button dates back to 1895, when the name was registered (Figure 7). 


\section{Presentation in the exhibition}

The museum exhibition was conceived chronologically. Special attention was devoted to technology in general and to the folk fastener. The button was presented within individual periods of time based on the technology of production and the material used. Uniform buttons were therefore incorporated in the category of metal fasteners from individual time periods. We can now only speculate as to the extent to which uniform buttons were presented. Only one complete exhibition tableau ${ }^{39}$ from the exhibition remains, presenting military buttons from the uniforms worn by the forces of Austro-Hungary, Prussia, Tsarist Russia, the Ottoman Empire, Romania, Switzerland and Bavaria. There are 107 buttons in total, all made after 1861 and not later than during WWI. Some of the original designations are incorrect. The tableau comes from the first reinstallation of the exhibition, in 1919 and 1920, during which the original brown cardboard mats were replaced by cardboard covered with grey-blue felt. The buttons were also newly attached in such a way that they could be easily removed if required. Logical assemblages of all related objects were created at the Waldes Museum. The strict separation of the collection into buttons and other fasteners only occurred when putting the pieces on record at the Museum of Glass and Jewellery.

\section{Uniform buttons and the publication work of the museum}

If we were to concentrate only on the specialised texts in Zprávy Waldesova musea, we would not have much to work with. The first issue deals with uniform buttons more than other topics, with two articles focusing on the subject. The first text is taken from another periodical, which was common practice for Zprávy Waldesova musea. The author of the article was Richard D. Steuardt ${ }^{40}$ from New York and was published in two parts under the title "Vojenské knoflíky z americké občanské války" (Military Buttons from the American Civil War). ${ }^{41}$ It is possible that the acquisition of American military buttons and the inclusion of this article in the museum magazine are linked to Waldes' frequent journeys to the USA. The study is short, but densely packed with information about the classification of buttons, the organisation of the army, the designs on buttons, production and trade, and provides significant examples. The other text on uniform buttons is, by contrast, a melancholy short story that presents the buttons from a military uniform as an important item of remembrance for family and friends. ${ }^{42}$ Military buttons are mentioned elsewhere in studies that focus on presenting the collections of other museums, but only very marginally so.

\section{The museum's archive and specialised library}

The museum began systematically building a specialised library and "archive of images" from the very outset. The materials preserved from both these collections were incorporated

\footnotetext{
${ }^{39} \mathrm{kw} 9 / 2018 \mathrm{a}, \mathrm{b}$ - The tableau was seriously damaged during the clearance of the museum by being cut into two.

${ }^{40}$ The name of the author was incorrectly stated as "Richard D. STENARD" in the first part published. Richard D. Steuart (1880-1951) was a prominent collector of buttons from the American Civil War. He came from Baltimore and his collection is mentioned in specialised literature.

${ }^{41}$ STEUART, Richard, D. Vojenské knoflíky z americké občanské války. 1. part. In: Zprávy musea knoflikư Jindrich Waldes Praba-Vrśovice (Zprávy Waldesova musea knoflikui), vol. 1, 1916, no. 1, pp. 8-12; STEUART, Richard, D. Vojenské knoflíky z americké občanské války. 2. část. In: Zprávy musea knoflikư Jindrich Waldes Praha-Vř̌ovice (Zpráuy Waldesova musea knoflikii). vol. 1, 1916, no. 2, pp. 37-39.

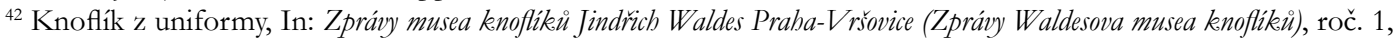
1916, č. 1, p. 23.
} 
in the Waldes Museum Archive after the museum closed. As a result, we now know the sort of two-dimensional materials that potential researchers had available to them. One, for example, is a volume of art prints with coloured depictions of Württemberg military uniforms from 1638 to 1854 , numbering 20 pages. ${ }^{43}$ Other material focussed on uniforms takes the form of a set of glass negatives that capture modern uniforms and medieval armour. ${ }^{44}$ The images are accompanied by photographs of soldiers from different armies. ${ }^{45}$ Articles from Austrian and German periodicals in particular are among the specialised materials. ${ }^{46}$

\section{Conclusion}

Uniform buttons are a sizeable part of the collection to have been preserved from the Waldes Museum - Collection of Clothing Fasteners. They are also important in terms of what they tell us. Unfortunately, we cannot prove that they were part of the elemental museum collection to which founder Jindrich Waldes was devoted. Most buttons became part of the collection during the first stage of the existence of the museum, the most active in terms of acquisitions. Even if the collection of uniform buttons was created by chance, a relatively representative assemblage was gathered, containing the traditional buttons of military and civilian uniforms and livery and the buttons of private enterprises or those of the servants of aristocratic families and church dignitaries. We cannot say with certainty whether all the uniform buttons identified were included in the permanent exhibition at the museum, although we can assume this was the case at least for those that still have reference numbers and can confirm it for buttons on the only exhibition tableau of this type of object which remains. Uniform buttons were also the subject-matter of publication activity in the museum periodical Zprávy Waldesova muzea, albeit to a lesser extent than for other collections. Other study materials on the topic were also gathered in the form of images and articles from periodicals of the time to serve the needs of potential researchers. The subject of uniform buttons is also considered in the unpublished monography written by E. M. Schranka, Der Knopf. In spite of various objections to the creation of this work, its merit lies mainly in having processed extensive and still-unused background research into sources, literature and periodicals.

The aim of the present article was to encapsulate the significance of uniform buttons in the collection and the activities of the "Waldes Museum". Uniform buttons were treated in the same way as other assemblages at the Waldes Museum, but were not given as much exposure in publication work. The documentary materials we still have to this day are preserved in the Waldes Museum Archive and the three-dimensional pieces that have survived are kept at the Museum of Glass and Jewellery in Jablonec nad Nisou, where they can serve researchers as useful reference material on the subject. The legacy of the Waldes Museum and of its collection remains to this day.

\footnotetext{
${ }^{43}$ MSB WM Archive, box M03.

${ }^{44}$ MSB WM Archive, box M113.

${ }^{45}$ MSB WM Archive, box M141.

${ }^{46}$ MSB WM Archive, boxes M58, M68.
} 


\section{References}

Archival sources

Museum of Glass and Jewellery in Jablonec nad Nisou, Waldes Museum Archive

Bibliography

AUZINGEROVÁ, Leopoldina (1916). Berlínskými musey. Studie věnovaná knoflíku. In: Zprávy musea knofliku Jindrich Waldes Praha-Vršovice (Zprávy Waldesova musea knoflikiu), vol. 1, no. 1, p. 3-5.

HOFMAN, Ješek (1919). Prưvodce sbirkami Waldesova muz̧ea v Praže-Vř̌ovicích. Praha: Politika.

HOFMAN, Ješek (1918). Waldesovo museum (Sbirka knoflikư a šatnich spinadel) v Praze-Vršovicích. Praha-Vršovice: Waldes \& Co.

HRUŠKOVÁ, Kateřina (2014). Sbirka Waldes. Jablonec nad Nisou: Museum of Glass and Jewellery in Jablonec nad Nisou, ISBN 978-80-86397-16-0.

HRUŠKOVÁ Kateřina (2018), Waldesovo muzeum knoflíků a spínadel v letech 1916-1945. In: Sbornik semináre k 100. výroči otevréni Waldesova muzea. Jablonec nad Nisou: Museum of Glass and Jewellery in Jablonec nad Nisou, Praha: Kotěrovo centrum architektury, o. p. s., ISBN 978-80-86397-32-0, p. 30-33.

HUGHES, Elizabeth - LESTER, Marion (1993). The Big Books of Buttons, Augusta, Maine: New Leaf Publishers, ISBN 0-9629046-0-0.

Important Civil War Auction, June 24, 2007, Gettysburg, Pennsylvania, Heritage Capital Corporation, Dallas, Texas, 2007, 2007. ISBN 9781599671505

JUNG, Peter (2001). Rakousko-uherská armáda za pruni svétové války. Brno: Computer Press. ISBN: 978-80-251-1520-6.

Knoflík z uniformy, In: Zprávy musea knofliku Jindrich Waldes Praha-Vršovice (Zprávy Waldesova musea knoflikì), roč. 1, 1916, č. 1, p. 23.

KRATOCHVÍL, Zdeněk (2017). Konflikt intepretací? In: OVČÁČKOVÁ, Lenka (ed.). O pưvodu kultury. Biologické, antropologické a historické koncepce kulturni evoluce. Praha: Academia, p. 11-21. ISBN 978-80-200-2751-1.

Masarykîv slovník naučný: lidová encyklopedie všeobecných vědomostí. DílIII, H-Kn. Praha:Československý kompas, 1927.

Masarykìv slovník nauinny: lidová encyklopedie všeobecných vědomostí. Díl VI., R-S. Praha: Československý kompas, 1932.

Ottiov slovník naučný: illustrovaná encyklopaedie obecných védomostí. 26, U-Vusín. Praha: J. Otto, 1907.

POTIER DE ECHELLES, Rudolf Franz Josef (1876). Kurzwarenindustrie (Knöpf) und Heerwaren. In: Wochenschrift des Niederösterreichischen Gewerbe-Vereines: Fachblatt für Gewerbe, Industrie und Handel, vol. 37, p. 452-453.

Sbírky. In: Zprávy Waldesova muzea knoflikui, vol. 2, 1917, no. 1, p. 24, 1917.

Sbírky. In: Zprávy Waldesova muzea knoflikù, vol. 3, 1918, no. 3-4, p. 69, 1918.

SEIPEL, Wilfried, WIECZOREK, Alfried (eds) (2000). Des Kaisers teure Kleider: Festroben und Ornate, Hofuniformen und Livreen vom frühen 18. Jahrhundert bis ins Zeitalter von Franz Joseph I. und Elisabeth. Wien: Kunsthistorisches Museum. ISBN 3-85497-010-2. 
SCHRANKA, Eduard Maria (1915), Der Knopf: Ein Stückchen Kulturgeschichte, Praha, 1915, typescript of a manuscript supplemented with corrections, rewritten at the Waldes \& Co. plant, Praha - Vršovice, Museum of Glass and Jewellery in Jablonec nad Nisou, Archiv Waldesova Muzea, box 64.

SQUIRE, Gwen (1976). Livery Buttons: The Pitt Collection. Chichester, Sussex: Leghorn Co. ISBN 0-95047-48-0-0

STEUART, Richard, D. (1916). Vojenské knoflíky z americké občanské války. 1. část. In: Zprávy musea knofliku Jindrich Waldes Praha-Vršovice (Zprávy Waldesova musea knoflikiu), vol. 1, no. 1, p. $8-12$.

STEUART, Richard, D. (1916). Vojenské knoflikky z americké občanské války. 2. část. In: Zprávy musea knoflikù Jindrich Waldes Praha-V ršovice (Zprávy Waldesova musea knoflikư). vol. 1, no. 2, p. 37-39.

VOGELTANZ, Jan (2009). Stejnokroje 1848-1849. Ceské Budéjovice: Karmášek. ISBN 978-8087101-11-7.

WALDES, Jindřich (1916). Moje museum. In: Zprávy musea knoflikủ Jindrüch Waldes Praha-Vř́ovice (Zprávy Waldesova musea knoflikui), vol. 1, is. 1, p. 1-2.

Wien Geschichte Wiki: Eduard Maria Schranka, accessed 12 January 2019, https://www. geschichtewiki.wien.gv.at/Eduard_Maria_Schranka. 